\title{
NILAI ETIKA DALAM TATANAN GLOBALISASI DAN DIGITALISASI BUDAYA Hery Gunawan
}

Universitas Katolik Widya Mandala Surabaya E-mail: herymail94@ gmail.com

Diterima:
20 Juni 2021
Direvisi:
8 Juli 2021
Disetujui:
14 Juli 2021

Abstrak

Globalisasi merupakan salah bentuk penjajahan modern, kini sebuah Negara tidak perlu mengirimkan pasukan untuk bertempur di medan perang tetapi cukup melalui perdagangan internasional maka sebuah Negara melalui industrinya dapat menata dan menjajah Negara lain. Fokus dari penelitian ini adalah menganalisa dan mengkritisi pergeseran nilai-nilai budaya lokal kedalam budaya asing yang sedikit demi sedikit mengikis nilai-nilai etika manusia sebagai makhluk sosial. Penelitian ini mencermati maraknya budaya asing yang sangat digemari kaum muda di Indonesia mulai dari bahasa, fashion hingga gaya hidup. berkembangnya budaya asing di Indonesia merupakan ancaman bagi kearifan lokal yang akan terkikis akibat globalisasi dan digitalisasi. Penelitian ini menggunakan metode deskriptif kualitatif dan teknik pengumpulan data adalah melalui observari dan studi literatur. Hasil penelitian menunjukkan banyak kaum muda di Indonesia yang lebih tertarik budaya asing daripada budaya lokal. Hal tersebut menyebabkan perubahan perilaku seperti cara berbusana, berkomunikasi hingga hilangnya etika pada generasi muda. Kemudahan untuk mendapatkan berbagai informasi mengenai budaya asing, mengakibatkan nilai-nilai budaya tersebut berhasil merubah tatanan sosial masyarakat Indonesia secara luas. K-pop merupakan budaya asing yang kini sangat digemari masyarakat dunia dan Indonesia, kaum muda sebagai target globalisasi dan digitalisasi telah berkontribusi membantu penyebaran budaya asing ke berbagai lapisan masyarakat khususnya Indonesia.

Kata kunci: Budaya; Globalisasi; Digitalisasi

\begin{abstract}
Globalization is a form of modern colonialism, now a country does not need to send troops to fight on the battlefield, but it is enough through international trade that a country through its industry can organize and colonize other countries. The focus of this research is to analyze and criticize the shift of local cultural values into foreign cultures which gradually erode the ethical values of humans as social beings. This study examines the proliferation of foreign cultures that are very popular with young people in Indonesia, ranging from language, fashion to lifestyle. The development of foreign culture in Indonesia is a threat to local wisdom which will be eroded due to globalization and digitalization. This research uses descriptive qualitative method and data collection technique is through
\end{abstract}


observation and literature study. The results of the study show that many young people in Indonesia are more interested in foreign culture than local culture. This causes changes in behavior such as the way of dressing, communicating to the loss of ethics in the younger generation. The ease of obtaining various information about foreign cultures has resulted in these cultural values successfully changing the social fabric of Indonesian society at large. K-pop is a foreign culture that is now very popular with the world community and Indonesia, young people as targets of globalization and digitalization have contributed to helping the spread of foreign culture to various levels of society, especially Indonesia.

Keywords: Culture; Globalization; Digitization

\section{Pendahuluan}

Globalisasi merupakan salah bentuk penjajahan modern (Riwanto, 2016), kini sebuah Negara tidak perlu mengirimkan pasukan untuk bertempur di medan perang tetapi cukup melalui perdagangan internasional maka sebuah Negara melalui industrinya dapat menata dan menjajah Negara lain (Putri, 2014). Senjata yang canggih tidak diperlukan untuk melancarkan serangan (Ashari, Jamsari, Safian, \& Safiai, 2020), cukup dengan bantuan teknologi informasi saja maka serangan dapat dilancarkan dan tidak perlu pasukan yang banyak untuk berperang, tetapi cukup memiliki pelanggan yang loyal dan fanatik terhadap produk dan jasa yang merupakan pasukan yang siap membela dan menjaga keberlangsungan perang ini. Teknologi merupakan ifluencer yang efektif terutama dalam menyebarkan pengaruh-pengaruh budaya ke berbagai belahan dunia tidak terkecuali Indonesia (Novianti, 2019), salah satunya adalah budaya Korean Pop (k-pop) yang meledak di seluruh dunia termasuk Indonesia (Pramadya \& Oktaviani, 2021).

Budaya korea masuk ke Indonesia sebagai salah satu bentuk globalisasi yang lebih popular disebut sebagai "Hallyu" (Pramita \& Harto, 2016), dahsyatnya Hallyu dapat dicermarti dari tingginya fans k-pop di Indonesia seperti fashion, musik pop, make up, model rambut, makanan, gaya bicaya dan bahasa korea makin digemari oleh kaum muda (Ummul Hasanah \& Mery Kharismawati, 2019). Efek dari sebuah industri ini belum pernah ada yang memiliki dampak yang luas dan bertahan lama, contohnya budaya barat dengan aliran Hip-Hop atau RnB yang sempat meledak juga pada tahun 2000an diseluruh dunia termasuk di Indonesia (Muhammad, 2018). Hal tersebut tidak bertahan lama dan cenderung tidak berkembang karena saat itu teknologi informasi belum berkembang secara pesat sehingga adanya batasan bagi masyarakat untuk mendapatkan informasi yang dicari (Prasetyo, 2018).

Berbeda dengan penelitian yang dilakukan oleh (Riwanto, 2016) yang lebih menekankan pada fenomena ekonomi dan tahapan globalisasi, penelitian ini lebih kepada dampak terhadap tatanan sosial dan perubahan perilaku manusia. Menurut (Nasution, 2017) keberhasilan budaya asing melekat pada suatu bangsa akan menjadi ancaman dan mengikis budaya lokal, hal tersebut cukup beralasan jika dilihat dari dampak yang dirasakan dimana kaum muda sebagai generasi penerus bangsa makin menggemari budaya asing daripada budaya lokal. Masalah yang timbul bukanlah sekuat apa budaya asing tersebut, tetapi bagaimana mempertahankan budaya lokal sebagai warisan dan nilai-nilai yang harus dilestarikan. Tujuan penelitian ini adalah untuk mengindikasi pergerseran nilainilai etika terhadap globalisasi dan digitalisasi, hasil penelitian ini diharapkan dapat 
bermanfaat untuk meningkatkan kesadaran masyarakat akan dampak globalisasi dan digitalisasi budaya serta untuk mengembangkan ilmu pengetahuan.

\section{Metode Penelitian}

Penelitian yang berjudul nilai etika dalam tatanan globalisasi dan digitalisasi budaya adalah penelitian kualitatif. Penelitian kualitatif menekankan pada pencarian makna, pengertian, konsep, karakteristik maupun deskripsi tentang sebuah fenomena. Teknik pengumpulan data menggunakan metode observasi yang dilakukan dengan cara nonparticipant observation dan studi literatur yang digunakan untuk mempertajam penelitian ini mengenai pergeseran budaya dan etika di era globalisasi dan digitalisasi. Obyek penelitian ini adalah budaya, dimana pengamatan lapangan dilakukan agar mendapatkan bukti konkrit serta dari fenomena-fenomena sosial yang terjadi di masyarakat. Dari pengamatan tersebut kemudian dikaji dengan literatur pendukung agar mendapatkan kesimpulan yang empiris

\section{Hasil dan Pembahasan}

\section{Soft Power: Budaya dan Teknologi 4.0}

Soft power adalah kemampuan dalam membentuk persepsi orang lain dengan cara membujuk dan menarik perhatian. Salah satu contoh soft power adalah budaya dan teknologi, dimana menurut E.B Tylor dalam (Setiadi, 2017), unsur budaya terdiri dari pengetahuan, kepercayaan, kesenian, moral, keilmuan, hukum, adat istiadat, kemampuan serta kebiasaan. Unsur-unsur budaya tersebut akan menjadi kekuatan yang sangat ampuh daripada sebuah persenjataan, budaya sebagai soft power dengan mudah akan masuk dan mengakar dalam sebuah masyarakat daripada persenjataan yang canggih. Soft power ini tidak menimbulkan korban jiwa, namun dapat menimbulkan ancaman yang serius terutama bagi sosial budaya sebuah bangsa, keberhasilan distribusi soft power ke dalam lapisan masyarakat akan merubah nilai-nilai etika dan akan menimbulkan gesekan antara yang bisa menerima dan tidak, gesekan tersebut terjadi karena adanya perbedaan persepsi mengenai unsur-unsur baru yang masuk dalam masyarakat.

Hallyu adalah soft power Korea dalam dunia hiburan saat ini. Menyebar melalui kecanggihan teknologi ke seluruh dunia dan menjadi bukti globalisasi budaya yang tengah terjadi di masyarakat, fans hallyu mencapai 100 juta jiwa pada tahun 2020 dan angka tersebut meningkat $11 \%$ dari tahun 2019 di seluruh dunia. Demam korea di Indonesia sendiri berawal dari masuknya drama korea dan K-pop kemudian untuk memperluas bisnisnya mulai diperkenalkan makanan, kosmetik dan fashion. Kampanye kebudayaan korea diperkenalkan dan disebarluaskan dengan memanfaatkan teknologi 4.0 seperti Youtube, Facebook, Instagram, Twitter dan produk-produk korea juga mudah ditemukan diberbagai platform e-commerce. E-commerce ternama lebih memilih artis/aktor K-pop sebagai brand ambassador daripada artis/aktor lokal dan bukannya tanpa alasan hal tersebut terjadi, artis/aktor K-pop dianggap lebih memiliki pengaruh daripada artis/aktor lokal dan dipercaya e-commerce yang menggunakan jasa mereka akan lebih menguntungkan.

\section{Budaya sebagai aset bangsa}

Industri hiburan Korea Selatan terus berkembang dan negara ini mendapat julukan "The Land of the Morning Calm" memilki keunggulan selain industri manufaktur yaitu industri jasa, kreatif dan digital. Keberhasilan K-pop juga mendorong sektor lain seperti industri fesyen dan kecantikan yang semakin digemari masyarakat di seluruh dunia, sehingga budaya sebagai aset merujuk kepada pertumbuhan perekonomian suatu negara dimana kesuksessan memperkenalkan budaya lokal menjadi budaya global akan menghasilkan devisa bagi negara itu sendiri. Kehadiran K-pop di Indonesia sendiri dapat 
mendorong perilaku berbelanja masyarakat khusunya kaum muda, dimana permintaan barang adaptasi Korea meningkat pesat dan hal tersebut akan meningkatkan nilai investasi juga (Diananto, 2021).

Aset adalah sumber daya yang memiliki nilai ekonomis. Budaya sebagai aset berarti budaya memiliki nilai ekonomis yang dapat dijual dan merupakan komoditas unggulan karena pengaruh yang ditimbulkan dari sebuah budaya tersebut, semakin luas budaya sebuah bangsa dikenal luas maka akan menambah nilai-nilai sebuah bangsa dan sebaliknya. Budaya sebagai aset karena berawal dari budaya yang dianut oleh sebuah masyarakat akan tercipta etika-etika yang berlaku di masyarakat, etika melalui budaya diturunkan generasi ke generasi agar nilai-nilai etika tetap berlaku di masyarakat. Era globalisasi menyebabkan tantangan untuk menjaga keutuhan budaya sebagai dasar pembentukan etika semakin sulit, masuknya budaya asing kerap kali menimbulkan perubahan diantaranya sistem atau tata nilai, mental, pola pikir hingga tingkah laku masyarakat secara luas (Umanailo, Sos, Umanailo, \& Sos, 2016)

\section{Etika sebagai jati diri Bangsa}

Globalisasi budaya sangat berpengaruh dan memiliki dampak yang luas khususnya dalam nilai-nilai etika yang diyakini masyarakat. Etika sendiri merupakan nilai-nilai yang mengatur manusia baik sebagai individu atau kelompok yang terkadang tidak tertulis tetapi diyakini sebagai nilai yang benar di masyarakat (Budi, 2019). Masyarakat menganggap budaya asing lebih menarik terutama kaum muda, yang gemar berpakaian dengan trend terbaru, meniru model dan warna rambut yang lagi hits tanpa melihat sisi kepantassan dan etika yang ada, kaum muda juga kerap mencampur bahasa nasional dengan bahasa asing saat berkomunikasi. Kaum muda sebagai tulang punggung Negara telah digerogoti oleh semangat budaya global dari berbagai sumber yang belum tentu sesuai dengan nilai-nilai etika yang ada, lalu bagaimana dengan kelangsungan budaya lokal yang merupakan jati diri dan identitas sebuah bangsa? Bagaimana dengan semua warisan budaya bangsa yang telah memberikan pengaruh positif terhadap perbaikan etika dari masa ke masa? Akankah hilang karena pengaruh globalisasi budaya asing lebih kuat? Akankah kaum muda sebagai penerus dan penjaga kearifan lokal hilang begitu saja karena gelombang globalisasi?

Globalisasi sendiri merupakan proses masuknya unsur-unsur baru dari berbagai belahan dunia kedalam sebuah tatanan sebuah Negara dan mengakibatkan perubahan sikap, perilaku dan pola pikir masyarakat dalam sebuah Negara (Hitt, Ireland, \& Hoskisson, 2016). Upaya untuk melestarikan nilai-nilai budaya tidak semata-mata dapat menyelamatkan bangsa dari arus globalisasi, budaya asing yang terus masuk melalui digitalisasi tidak mudah dibendung apalagi hanya diacuhkan saja. Etika sebagai jati diri bangsa memerlukan kedewasaan mental agar dapat membedakan yang baik dan buruk serta mengetahui batasan-batasan mengenai etika (Bleibleh \& Awad, 2020).

Tujuan dari globalisasi dan digitalisasi pada dasarnya adalah bagaimana menata kembali manusia melalui sistem teknologi, alasanya karena dampak yang paling terasa dan terlihat adalah revolusi manusia itu sendiri. Manusia merupakan obyek globalisasi dan digitalisasi dimana perubahan pola pikir, tingkah laku, hubungan, pola bepergian, belajarmengajar dan sebagainya merupakan bukti konkrit manusia adalah target revolusi itu sendiri. Menteri Keuangan Sri Mulyani berpesan agar jangan meninggalkan etika dalam era digital karena globalisasi akan berdampak positif jika berlandaskan etika. Dampak yang terkadang kurang disadari adalah keberadaan etika yang tidak lagi penting dan tidak diperlukan dalam dunia virtual, etika sudah tidak relevan dalam dunia digital karena teknologi dianggap dapat mewakili perasaan, simpati dan cinta. Etika dianggap terlalu bertele-tele, terlalu formal karena banyaknya aturan yang harus dipahami dan ditaati 
sehingga etika banyak ditinggalkan oleh sebagian orang terutama kaum muda yang belum dewasa.

\section{Kampanye "mencintai poduk lokal"}

Hingga hari ini sektor mana yang tidak terpengaruh globalisasi dan digitalisasi? Saya kira tidak ada dan secara masif perlahan-lahan globalisasi dan digitalisasi akan membunuh produk lokal, artinya fenomena globalisasi pada akhirnya hanya dirasakan oleh beberapa orang yang paham dan mampu mengelola teknologi. Globalisasi kurang berpihak kepada usaha mikro, kecil dan menengah (UMKM), sehingga Presiden Jokowi berusaha melindungi dan memberdayakan produk lokal dengan mengajak seluruh masyarakat untuk "membenci"produk asing dan mencintai produk lokal. Ajakan tersebut bukan tanpa alasan, produk asing lebih mendapat tempat strategis dan perhatian khusus dari pengelola bisnis, hal tersebut dipicu dari realita masyarakat yang lebih suka pada produk asing dan bermerk. Orang indonesia sebanyak $60 \%$, lebih suka produk asing karena daripada produk lokal, sehingga hal tersebut menyebabkan peningkatan import barang dari beberapa negara terutama Tiongkok.

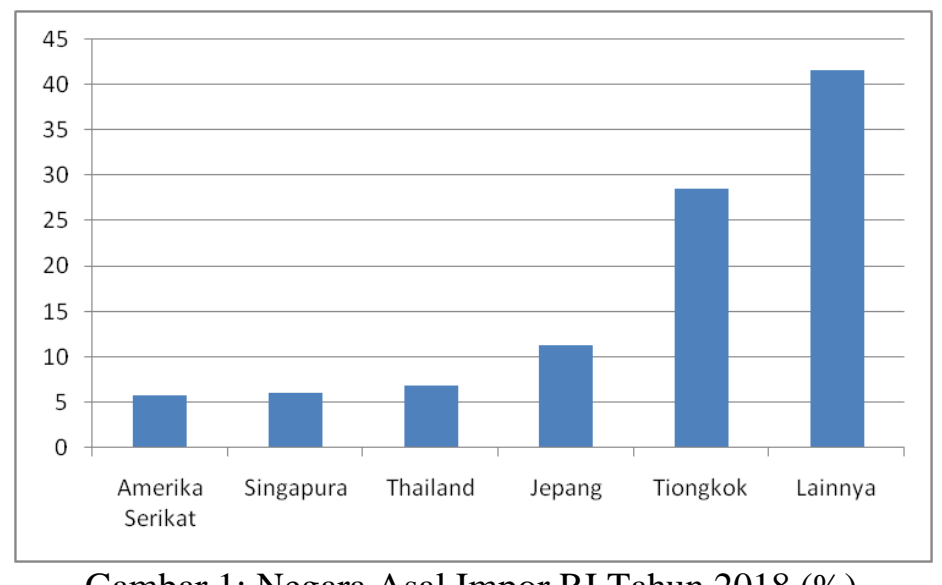

Gambar 1: Negara Asal Impor RI Tahun 2018 (\%)

Sumber : Badan Pusat Statistik

Bukti konkrit yang dapat kita lihat dari banyaknya gerai dengan merk asing di pusat perbelanjaan dan masyarakat lebih suka memakai baju yang betuliskan "I love SGD atau I love $H K G$ ", menggunakan tas bermerk serta kosmetik asing karena ingin tampil seperti idolanya. Fenomena tersebut justru datang dari kalangan menengah keatas yang memiliki modal yang cukup dan hal tersebut dinilai sebagai bisnis yang menjanjikan bagi pusat perbelanjaan. Fenomena tersebut juga mengindikasikan bahwa masyarakat menengah keatas memiliki budaya untuk berbelanja produk asing daripada produk lokal, sedangkan UMKM jika hanya berharap kepada masyarakat menengah kebawah maka tidak akan berkembang dengan baik, karena terbatasnya modal dan daya beli. Bisnis kerap kali dibangun dan berkembang jika memiliki modal besar, keberhasilan globalisasi dan digitalisasi dapat dicapai oleh negara-negara yang memiliki modal, teknologi dan tingkat indeks pengembangan manusia yang unggul, sedangkan negara miskin dan berkembang hanya menjadi sasaran bagi negara-negara dengan kekuatan sumber daya yang unggul dan maju.

Idealnya globalisasi dan digitalisasi harus bisa memberikan kesempatan yang sama untuk maju dan berkembang, sehingga hal tersebut juga merupakan bisnis yang memiliki etika karena memberikan kesempatan yang sama merupakan bentuk penghargaan dan 
penghormatan bagi setiap individu untuk mendapatkan kehidupan yang layak. Etika memberikan batasan-batasan dalam menghadapi era globalisasi dan digitalisasi, karena bisnis yang beretika menganggap pesaing dan masyarakat sebagai mitra bisnis yang bisa memberikan manfaat bagi masyarakat luas (Budi, 2019).

\section{Globalisasi dan Digitalisasi sebagai bentuk kebebasan}

Menurut Kamus Besar Bahasa Indonesia (KBBI), bebas berarti tanpa halangan dan gangguan. Kebebasan salah satu produk dari globalisasi dan digitalisasi, batasan-batasan perdagangan, budaya dan informasi hilang karena teknologi yang memangkas jarak sebagai tanda dimulainya tatanan baru dalam revolusi 4.0. Kebebasan berekspresi adalah tindakan yang memuat karakteristik dari sikap ekspresif yang mencakup komunikasi, informasi dan pengaruh. Kebebasan tersebut diakomodir oleh kehadiran teknologi sebagai media yang atraktif dan ekspresif bagi sebagian orang yang impulsif untuk mengekspresikan kebebasannya dalam bentuk tulisan dalam dunia digital. Masyarakat rajin dan tekun memposting foto, komentar dan status tentang perasaan, fenomena hingga makian dan cacian terhadap suatu peristiwa yang sedang viral sehingga tampak perilaku tersebut tidak beretika dan berbudaya.

Kebebasan berekspresi merupakan dampak dari globalisasi dan digitalisasi, masyarakat dengan bangganya mengadopsi budaya asing sebagai identitas baru mereka yang didapat dari berbagai media digital. Masyarakat bebas untuk mencari informasi mengenai apapun yang disukai dan sedang viral, masyarakat juga secara bebas dapat belajar berbagai hal di dunia ini terutama budaya asing dengan segala keunikannya. Bentuk-bentuk kebebasan tersebut diadopsi oleh masyarakat dan secara perlahan-lahan akan merubah tatanan sosial sebuah masyarakat dan akhirnya merubah identitas bangsa secara keseluruhan. Cara untuk mengatasi dan mencegah pengaruh buruk dari globalisasi, perlu adanya penguatan nilai-nilai budaya lokal yang menjadi identitas dan perekat dalam masyarakat. Penguatan nilai budaya-budaya lokal tentu saja tergantung dari kesediaan masyarakat dalam menjaga nilai-nilai tersebut, jika budaya asing lebih diterima daripada budaya lokal maka pergeseran budaya akan terjadi dan sebaliknya.

Tantangan globalisasi dan digitalisasi justru mengenai bagaimana menjaga keutuhan masyarakat sebagai benteng dari kuatnya arus globalisasi dan digitalisasi, melestarikan etika dan budaya tidak bisa hanya dari pemerintah atau masyarakat saja, tetapi kerjasama keduanya sangat diperlukan untuk melestarikan identitas bangsa. identitas bangsa bersifat kekal dan asli sedangkan bentuk identitas lain seperti jenis kelamin, kelas sosial, agama bersifat sementara dan akan berubah sesuai situasinya. Identitas nasional akan melekat pada diri setiap orang yang dinilai berdasarkan etika yang dimilikinya, jika kita bertingkah laku buruk maka orang lain secara tidak langsung akan menilai buruk budaya kita dan sebaliknya jika kita bertingkah laku baik maka kita akan dinilai sebagai bangsa dengan budaya yang baik pula. (Antonsich, 2011). Kita boleh tertarik dengan budaya asing apapun, tetapi harus dalam batasan yang wajar dimana kita tidak boleh mengadopsi budaya asing tersebut sebagai identitas nasional. Karena budaya asing tersebut belum tentu sesuai dengan etika yang dianut dalam masyarakat.

Budaya asing yang dipaksakan akan menimbulkan gesekan-gesekan antara yang bisa menerima dan tidak bisa menerima, kemudian gesekan tersebut akan menimbulkan perpecahan di masyarakat, dari perpecahan yang kecil akan menimbulkan perpecahan tatanan sosial secara luas dan pada akhirnya menghancurkan peradaban sebuah bangsa. Persamaan etika dan budaya adalah sama-sama menyangkut perilaku manusia, kedua hal tersebut membentuk dan mengatur perilaku manusia agar menjadi pribadi yang lebih baik, dengan kata lain etika dan budaya memeberikan batasan antara yang boleh dilakukan dan tidak boleh dilakukan, baik-buruk dan benar-salah sebuah perbuatan. Sehingga budaya 
merupakan sumber atau induk dari penanaman dan pembentukan nilai-nilai etika yang berlaku di masyarakat dan budaya juga merupakan dasar pembetukan aturan-aturan atau norma-norma dalam tatanan sosial.

\section{Etika dalam tatanan globalisasi dan digitalisasi budaya}

Revolusi industri melahirkan teknologi-teknologi yang canggih yang menjadi teman hidup dan menghubungkan kita dengan orang diseluruh dunia. Apakah kita benar-benar terhubung satu sama lain dalam ikatan emosional? antropologi manusia kini telah bergeser ke dunia digital, dimana manusia cenderung memilih pola narsistik senagai bentuk relasi baru (Riyanto, 2019). Kita perlu mencermati perubahan tersebut dimana manusia lebih percaya dan yakin dengan teknologi yang canggih daripada hubungan sosialnya dan interaksi lebih banyak terjadi dalam dunia maya seperti media sosial dan chat engine. Manusia merasa praktis dengan hanya mengirimkan pesan eletronik atau sekedar videocall daripada harus kumpul dalam komunitas yang membuang tenaga dan waktu, manusia kini cukup mengirimkan pesan sebagai bentuk perhatian dan cinta kepada teman tanpa perlu bertemu satu sama lain. Digitlaisasi yang mengglobal justru sebagai penghalang manusia dalam memupuk cinta kasih dan etika.

Prinsip Utilitarianism dapat mengkaji suatu perbuatan bisa dikatakan baik jika memilki manfaat bagi orang banyak dan bukan hanya bagi dirinya sendiri. Prinsip ini menekankan manfaat atau nilai guna dari perbuatan seseorang terhadap lingkungannya. Keberagaman budaya diseluruh dunia memang sangat menarik untuk dikagumi, tetapi perlu diingat mengagumi bukan berarti kita meninggalkan identitas kita sehingga rasa nasionalisme kita juga luntur. Rasa kagum yang berlebihan merupakan salah satu indikasi gangguan jiwa, dimana penggemar berusaha meniru budaya asing atau idolanya dan mereka merasa marah jika terjadi penghinaan dan penolakan. Kekaguman yang berlebihan akan menimbulkan perselisihan dan perpecahan di masyarakat, sebagian yang menilai ketidaksesuaian budaya asing akan menolak dan akhirnya menimbulkan dampak sosial yang berkepanjangan dari generasi ke generasi.

Kaum muda yang terobsesi akan sebuah budaya asing merupakan ancaman bagi keberlangsungan budaya lokal, karena saat seseorang terobsesi maka pikirannya akan terganggu dan akibat pikiran yang terganggu tersebut akan menyebabkan perilaku yang kompulsif. Seseorang akan kehilangan kendali atas dirinya, perasaan, dan kemampuan untuk berpikir logis. Hal tersebut juga menimbulkan sifat hedonis yang berlebihan, dimana seseorang tidak segan-segan membelanjakan uangnya untuk membeli produk-produk asing meskipun lebih mahal. Pergeseran perilaku masyarakat tersebut merupakan ancaman bagi keberlangsungan budaya lokal dan tantangannya adalah bagaimana cara melestarikan budaya lokal sebagai identitas sebuah bangsa?

Pelestarikan budaya lokal dapat dilakukan melalui dua cara yaitu:

\section{Culture Experience}

Merupakan pelestarian budaya yang dilakukan dengan cara berpartisipasi langsung dalam mempelajari dan meyebarluaskan salah satu budaya lokal.

\section{Culture Knowledge}

Merupakan bentuk pelestarian budaya dengan cara membangun pusat informasi bagi konvensional maupun secara digital yang bertujuan sebagai sarana edukasi ataupun untuk kepentingan pengembangan kebudayaan lokal dan potensi kepariwisataan daerah tertentu.

Kedua metode tersebut diharapkan kaum muda dari generasi ke generasi dapat mengenal budaya lokal dengan benar, sehingga budaya lokal tidak akan hilang akibat dampak dari globalisasi budaya asing. Hal tersebut juga upaya menjaga agar budaya nasional tidak diambil atau dicuri oleh bangsa lain. 


\section{Kesimpulan}

1. Dampak positif dari globalisasi dan digitalisasi adalah menggerakkan roda perekonomian suatu negara, akibat globalisasi dan digitalisasi produk dan jasa lebih cepat disampaikan dan ditemukan oleh pelanggan. Keberadaan teknologi informasi sebagai mediasi merupakan sarana yang kuat untuk menyebarluaskan soft power yang dimiliki berbagai negara.

2. Salah satu bentuk soft power adalah budaya, budaya merupakan aset dan identitas sebuah bangsa. Budaya yang dikelola dengan baik akan berkembang secara global dan jika semakin dikagumi oleh masyarakat luas, maka pengagum tersebut merupakan pasukan yang siap membela budaya tersebut.

3. Tantangan globalisasi dan digitalisasi budaya, bukan bagaimana sebuah bangsa menyeleksi budaya asing yang masuk. Tetapi bagaimana atau dengan cara apa sebuah bangsa mempertahankan budaya lokal agar tidak dilupakan dan hilang karena arus globalisasi dan digitalisasi.

4. Kaum muda sebagai generasi penerus kebudayaan justru lebih memilih budaya asing untuk diadopsi kedalam tatanan sosial masyarakat. Cara berpakaian dan bertutur kata para generasi muda kini sangat bervariatif karena budaya asing yang lebih dominan dan digemari. Hal tersebut merupakan fenomena pergeseran nilai-nilai etika dalam globalisasi dan digitalisasi.

5. Melestarikan budaya lokal bukan hanya tugas dari pemerintah, budaya sebagai jati diri suatu bangsa harus dibangun dari komitmen seluruh lapisan masyarakat. Terlepas dari perbedaan suku, agama dan ras, semuanya yang mendiami dan hidup dalam suatu tatanan masyarakat wajib memperhatikan nilai-nilai budaya dan etika sebagai acuan untuk berperilaku.

6. Semakin terbukanya suatu bangsa maka semakin heterogen pula budaya yang dimiliki dan sebaliknya, keberagaman budaya harus diadopsi sewajar mungkin tanpa fanatisme yang berlebihan. Mencintai budaya lokal sama seperti mencintai diri sendiri sebagai bagian dari sumber daya dalam era globalisasi dan digitalisasi dan selektif dalam memilih budaya yang sesuai adalah ciri sumber daya yang beretika

\section{Bibliografi}

Antonsich, Marco. (2011). National identities in the age of globalisation: The case of Western Europe. National Identities, 11(3), 281-299.

Ashari, Mohamad Zulfazdlee Abul Hassan, Jamsari, Ezad Azraai, Safian, Nursafira Lubis, \& Safiai, Mohd Hafiz. (2020). Sejarah Pembangunan Teknologi Ketenteraan Kerajaan Banu Marin di Al-Maghrib. Journal of Al-Tamaddun, 15(2), 147-161.

Bleibleh, Sahera, \& Awad, Jihad. (2020). Preserving cultural heritage: Shifting paradigms in the face of war, occupation, and identity. Journal of Cultural Heritage, 44, 196203. https://doi.org/https://doi.org/10.1016/j.culher.2020.02.013

Budi, Prihatminingtyas. (2019). Etika Bisnis Suatu Pendekatan dan Aplikasinya Terhadap Stakeholders. Purwokerto: CV IRDH.

Hitt, Michael A., Ireland, R. Duane, \& Hoskisson, Robert E. (2016). Strategic management: concepts: competitiveness and globalization. America: Cengage Learning.

Muhammad, Soghi. (2018). Jaringan Sosial Asosiasi Komunitas Musisi Indie Indonesia (ASKOMINDO). Jakarta: Fakultas Ilmu Sosial Dan Ilmu Politik UIN Syarif Hidayatullah.

Novianti, Evi. (2019). Komunikasi Budaya dan Dokumentasi Kontemporer. In Unpad Press. Bandung: Unpad Press. 
Volume 1, Nomor 7 , Juli 2021

p-ISSN 2774-7018; e-ISSN 2774-700X

Pramadya, Teguh Puja, \& Oktaviani, Jusmalia. (2021). Korean Wave (Hallyu) dan Persepsi Kaum Muda di Indonesia: Peran Media dan Diplomasi Publik Korea Selatan. Insignia: Journal of International Relations, 8(1), 87-100.

Pramita, Yuli, \& Harto, Syafri. (2016). Pengaruh Hallyu terhadap minat masyarakat Indonesia untuk berwisata ke Korea Selatan. Riau University.

Prasetyo, Joko. (2018). Perubahan Perilaku Remaja oleh Teknologi Informasi di Desa Pekuwon Kecamatan Juwana Kabupaten Pati. Universitas Negeri Semarang.

Putri, Feby Dasa Eka. (2014). Krisis Minyak Tahun 1973-1974 di Negara-negara Industri sebagai Penggerak Tata Ekonomi Dunia Baru. AVATARA, Journal Pendidikan Sejarah, 2, 42-57.

Riwanto, Riwanto. (2016). Globalisasi Perubahan Sosial Budaya Dan Krisis Multidimensi Di Indonesia. Social Studies, 4(2), 17-29.

Riyanto, F. X. E. K. O. Armada. (2019). "Percikan" Revolusi 4.0 Refleksi Filosofis Tentang Siapa Manusia Dan allah. Seri Filsafat Teologi, 29(28), 1-25.

Setiadi, Elly M. (2017). Ilmu sosial \& budaya dasar. Jakarta: Kencana.

Umanailo, M. Chairul Basrun, Sos, S., Umanailo, M. Chairul Basrun, \& Sos, S. (2016). Ilmu sosial budaya dasar. Kediri: FAM PUBLISHING.

Ummul Hasanah, S. S., \& Mery Kharismawati, S. S. (2019). Penggunaan budaya pop korea dalam proses pembelajaran bahasa korea bagi mahasiswa dengan gaya belajar campuran. Jurnal Lingua Applicata, 3(1), 17-31.

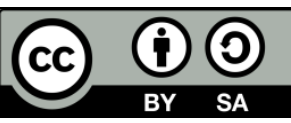

This work is licensed under a Creative Commons AttributionShareAlike 4.0 International License. 